INTENSIF, Vol.3 No.1 February 2019

ISSN: 2580-409X (Print) / 2549-6824 (Online)

Website: http://ojs.unpkediri.ac.id/index.php/intensif

\title{
Analisis Pengaruh Sistem Keamanan Informasi Perbankan pada Nasabah Pengguna
} Internet Banking Analysis of Influence of Banking Information Security System to Internet Banking User Customer

\author{
${ }^{1}$ Indra Ava Dianta, ${ }^{2}$ Edwin Zusrony \\ ${ }^{1,2}$ Sekolah Tinggi Elektronika dan Komputer \\ ${ }^{1,2}$ Semarang, Indonesia \\ E-mail: ${ }^{1}$ indra@stekom.ac.id, ${ }^{2}$ edwin.zusrony@stekom.ac.id
}

\begin{abstract}
Abstrak - Pelayanan produk perbankan yang aman wajib dimiliki oleh semua provider untuk dapat bersaing secara kompetitif di era digital saat ini. Keamanan sistem informasi dalam transaksi layanan perbankan khususnya fitur Internet Banking menjadi sangat penting guna mendukung pelayanan yang akuntabel. Dalam sistem keamanan informasi atau komputer ada 3 dimensi yang dinilai, yaitu confidentiality, integrity, dan availability. Ketiga dimensi diterapkan kepada responden karyawan PT. XYZ Salatiga dengan menggunakan teknik Forum Group Discussion (FGD). Output penelitian ini menunjukkan mayoritas dari keseluruhan karyawan PT. XYY Salatiga sebesar 80\%, menyatakan bahwa dimensi availability dengan indikator access speed adalah yang paling mempengaruhi keamanan sistem informasi fitur Internet Banking. Hal ini dapat dijadikan rekomendasi bagi Bank BCA dalam hal peningkatan data security khususnya terkait Internet Banking.
\end{abstract}

Kata Kunci- Sistem Keamanan Informasi, Internet Banking, Forum Group Discussion

Abstract - A secure banking world service is an absolute requirement to compete competitively in today's digital age. Information system security in banking services transaction especially Internet Banking feature becomes very important to support accountable service. In the information security system or computer there are 3 dimensions are assessed, namely confidentiality, integrity, and availability. The three dimensions applied to the respondents of employees of PT. XYZ Salatiga using Forum Group Discussion (FGD) technique. The results of this study show that most of the employees of PT. XYY Salatiga of $80 \%$, stated that the availability dimension with the access speed indicator is the most affect the security of information system of Internet Banking feature. This can be a recommendation for Bank BCA in terms of increasing data security especially related to Internet Banking.

Keywords - Information Security System, Internet Banking, Forum Group Discussion 
INTENSIF, Vol.3 No.1 February 2019

ISSN: 2580-409X (Print) / 2549-6824 (Online)

Website: http://ojs.unpkediri.ac.id/index.php/intensif

\section{PENDAHULUAN}

Layanan perbankan untuk transaksi keuangan banyak diberikan oleh bank dengan tujuan utama memberikan kemudahan nasabah dalam bertransaksi. Selain pelayananan di kantor bank, terdapat layanan menggunakan internet banking dan juga ATM [1]. PT. XYZ adalah merupakan perusahaan pembiayaan tingkat nasional dimana memiliki jaringan diseluruh Indonesia. PT. XYZ memiliki beberapa cabang di wilayah Jawa Tengah, dimana salah satunya ada di kota Salatiga. Mayoritas karyawan PT. XYZ memakai tabungan atau rekening BCA untuk pembayaran gaji.

Tingginya kebutuhan akan bertransaksi yang mudah, aman dan cepat menuntut setiap bank meningkatkan pelayanan khususnya di bidang keamanan sistem informasi, agar dapat menjawab tantangan saat ini berupa cyber crime [2]. Saat ini nasabah lebih memilih bertransaksi melalui delivery channel alternatif seperti ATM, Internet Banking, SMS Banking, bukan melalui antri di bank [3]. Dengan semakin banyaknya transaksi berbasis online maka memicu meningkatnya penggunaan delivery channel alternative, contohnya seperti Internet Banking, dimana sudah menjadi kebutuhan wajib bagi kaum urban dan milineal saat ini, tidak terkecuali karyawan PT. XYZ. Perkembangan teknologi sangat berpengaruh terhadap penerapan Internet Banking, guna mewujudkan transaksi perbankan yang mudah, cepat, dan aman. Adanya realita ini pihak perbankan wajib memperhatikan keamanan dalan sistem informasi, dimana merupakan komponen penting agar tetap menjadi pilihan nasabah. Penelitian ini mencoba mengidentifikasi persepsi nasabah tentang pengaruh keamanan sistem informasi pada Bank BCA [4].

Sistem informasi dapat diterjemahkan sebagai kumpulan dari berbagai cara yang diorganisir untuk proses pengumpulan, pemasukan, pengolah, penyimpan, dan pengendalian data, dimana akan dilaporkan guna mencapai tujuan organisasi [5][6]. Keamanan sistem informasi dapat didefinisikan sebagai pengoperasian sebuah sistem dari semua bentuk mekanisme yang memiliki tujuan agar sistem tersebut terhindar dari berbagai threat's yang memberi efek buruk terhadeap keamanan information data dan keamanan system actors. [7].

Adanya perkembangan zaman dan teknologi yang cepat dan berbagai bentuk ancaman dalam menghadapi keamanan nasional akan berubah. Kini ancaman dapat pula terjadi di dunia virtual atau lebih dikenal kejahatan dunia siber. Beberapa kasus cyber crime diantaranya adalah kejahatan yang dilakukan oleh oknum-oknum jahat melalui media sosial dan internet dan terbukti sedikit banyak mengganggu national security [2].

Internet Banking adalah sebagai pelayanan perbankan kepada nasabah atau pelanggannya yang bertujuan memudahkan nasabah dalam hal pengecekkan saldo dan melakukan pembayaran setiap transaksi perbankan secara online 24 jam tanpa harus hadir ke kantor cabang [4]. 
Bank semakin kuat mengembangkan layanan internet banking karena kemajuan internet dan manfaatnya, serta semakin banyak pengguna internet di dunia [8]. Oleh karenanya, potensi yang ada saat ini bagus bagi bank untuk mengembangkan layanan berbasis internet. Kondisi ini menciptakan peluang dan daya tarik sektor perbankan yang mengundang munculnya pendatang baru [8]. Akibatnya, persaingan antar bank semakin kompetitif dalam memberikan layanan yang terbaik, layanan 24 jam setiap harinya, akses yang mudah dan murah dengan berbagai macam jenis transaksi [7].

Berikut merupakan jenis sistem keamanan yang dipakai dalam internet banking menurut Lewis dan Thygerson [9] dalam [4], yaitu:

\section{Cryptography System}

Sistem dimana menggunakan berbagai angka yang sering disebut dengan key. Sistem memiliki fungsi melakukan pengenalan terhadap seorang nasabah dan melindungi semua informasi finansial nasabah.

\section{Firewall System}

Sistem ini berfungsi untuk melakukan pencegahan terhadap pihak-pihak yang tidak mendapat izin dalam memasuki area yang dilindungi atau diproteksi dalam unit pusat kerja suatu perusahaan. Firewall system tidak dapat mencegah adanya virus dan ini murni kendala internal organisasi.

Ada beberapa aspek keamanan komputer wajib diperhatikan dan mempunyai beberapa lingkup penting, dimana menurut Lewis dan Thygerson [9] dalam [4], yaitu :

\section{Privacy \& Confidentiality}

Aspek ini menekankan pada usaha dalam menjaga kerahasiaan data dan informasi dan pihak lain tidak boleh mengaksesnya. Sedangkan privacy lebih menekankan pada datadaata privat, contohnya data tentang nasabah perbankan.

\section{Integrity}

Aspek integrity memprioritaskan keamanan data atau informasi agar tidak bisa diakses selain tanpa seizin pemilik.

\section{Authentication}

Aspek yang menekankan mengenai orosinalitas suatu data atau informasi, termasuk didalamnya pihak yang memberi data atau mengaksesnya tersebut merupakan pihak yang memiliki ijin akses atau pemilik sah.

4. Availability

Aspek yang berkaitan dengan ketersediaan informasi ketika dibutuhkan. 
INTENSIF, Vol.3 No.1 February 2019

ISSN: 2580-409X (Print) / 2549-6824 (Online)

Website: http://ojs.unpkediri.ac.id/index.php/intensif

\section{METODE PENELITIAN}

\section{A. Pengumpulan Data}

Metode pengumpulan data diperoleh dengan menggunakan tahapan susrvey dan wawancara dengan Focus Group Discussion Technique. FGD Technique Menurut Paramita [10] dilakukan untuk mendapatkan persepsi responden terhadap suatu topik sesuai dengan kebutuhan dan tujuan penelitian [11]. Focus Group Discussion Technique disarankan berjumlah antara 8 sampai dengan maksimal 12 orang dan [12].

\section{B. Karakteristik Responden}

Penelitian dilakukan di PT. XYZ cabang Salatiga ini, teknik yang dilakukan dalam pengumpulan data kepada responden melalui proses polling tanya jawab kepada 10 orang karyawan dengan bertatap muka dengan FGD technique, dimana penentuan responden menggunakan metode purposive sampling. Karyawan terdiri dari 7 orang supervisor dan 3 orang staf. Kegiatan survei responden dilakukan tanggal 14 sampai dengan 19 Mei 2018.

\section{HASIL DAN PEMBAHASAN}

\section{A. Evaluasi Dimensi Confidentiality}

Pada dimensi confidentiality Bank BCA dimana evaluasi sistem keamanan informasi berdasarkan persepsi karyawan PT. XYZ dengan menjawab pertanyaan tentang seberapa besar pengaruh keamanan data nasabah (Customer Data Security). Dari pertanyaan di atas maka didapatkan hasil rekapitulasi persentase jawaban karyawan PT. XYZ pada dan gambar 1.

\section{Confidentiality}

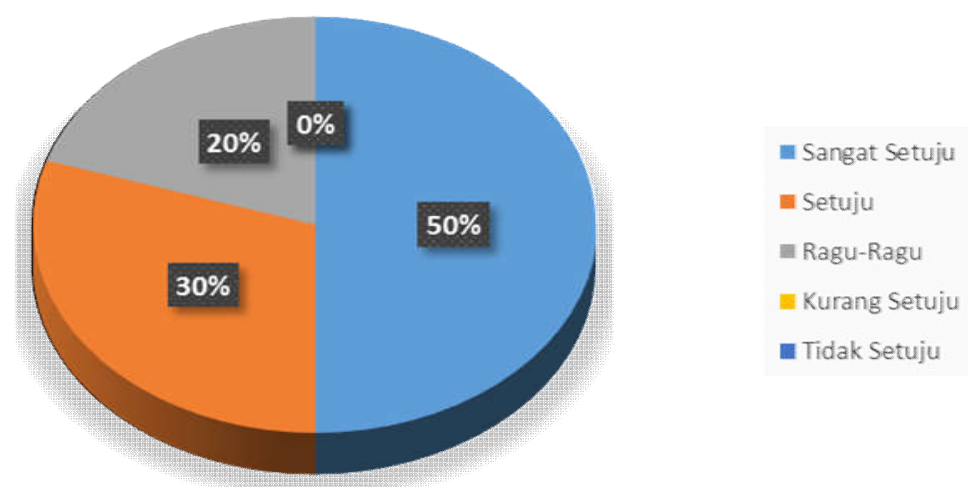

Gambar 1. DIAGRAM REKAPITULASI JAWABAN KARYAWAN TENTANG CONFIDENTIALITY 
INTENSIF, Vol.3 No.1 February 2019

ISSN: 2580-409X (Print) / 2549-6824 (Online)

Website: http://ojs.unpkediri.ac.id/index.php/intensif

Berdasarkan rekapitulasi pada gambar 1 maka sebanyak 50\% karyawan PT. XYZ Salatiga sangat setuju bahwa confidentiality menjadi pengaruh keamanan sistem informasi fitur Internet Banking Bank BCA. Sebanyak 30\% setuju, 20\% ragu-ragu dan masing - masing 0\% untuk jawaban kurang setuju dan tidak setuju.

\section{B. Evaluasi Dimensi Integrity}

Ada 3 komponen dalam dimensi Integrity yang dijadikan indikator yaitu Accuracy and Consistency, Preventive Mechanism dan Detective Mechanism.

\section{Accuracy and Consistency}

Accuracy and consistency merupakan tingkat kepercayaan terhadap suatu informasi yang mencakup akurasi dan konsistensi terhadap informasi yang ada. Gambar 2 merupakan perbandingan nilai persentase karyawan PT. XYZ tentang accuracy and consistency.

\section{Accuracy \& Consistency}

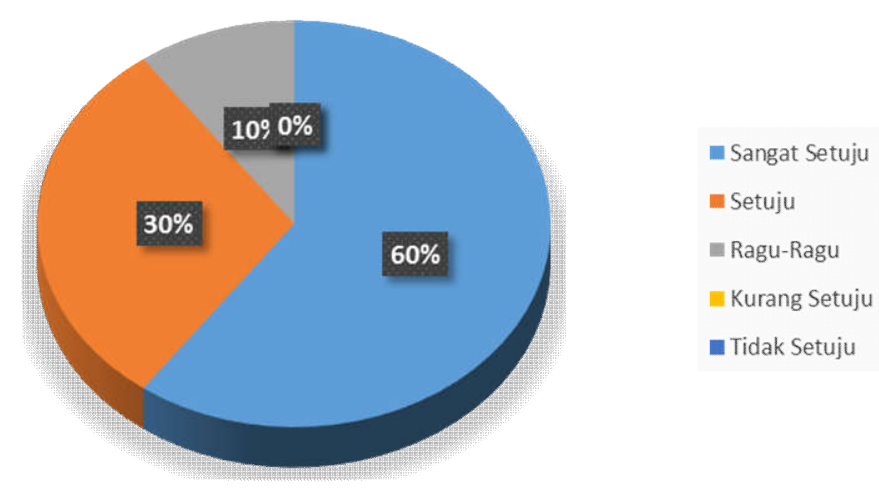

\section{Gambar 2. DIAGRAM REKAPITULASI ACCURACY AND CONSISTENCY}

Berdasarkan rekapitulasi pada gambar 2 maka sebanyak 60\% karyawan PT. XYZ Salatiga sangat setuju bahwa accuracy and consistency menjadi pengaruh keamanan sistem informasi fitur Internet Banking Bank BCA. Sebanyak 30\% setuju, 10\% ragu-ragu, dan masing - masing $0 \%$ untuk jawaban kurang setuju dan tidak setuju.

\section{Preventive Mechanism}

Preventive mechanism merupakan kontrol akses untuk menghalangi terjadinya modifikasi data oleh pihak luar. Gambar 3 merupakan perbandingan nilai persentase karyawan PT. XYZ tentang preventive mechanism. 
INTENSIF, Vol.3 No.1 February 2019

ISSN: 2580-409X (Print) / 2549-6824 (Online)

Website: http://ojs.unpkediri.ac.id/index.php/intensif

\section{Accuracy \& Consistency}

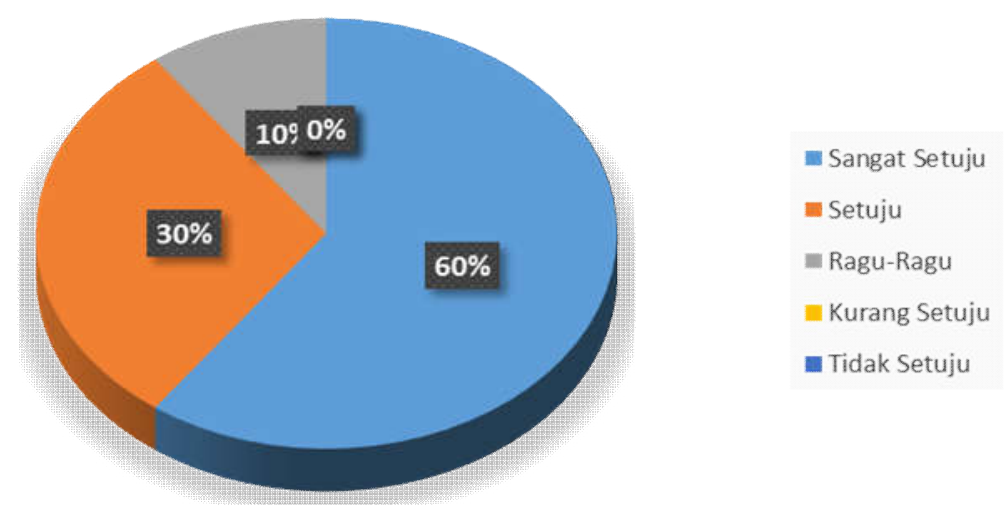

\section{Gambar 3. DIAGRAM REKAPITULASI ACCURACY AND CONSISTENCY}

Berdasarkan rekapitulasi pada gambar 3 maka sebanyak 70\% karyawan PT. XYZ Salatiga sangat setuju bahwa human error menjadi pengaruh keamanan sistem informasi fitur Internet Banking Bank BCA. Sebanyak 70\% sangat setuju, 30\% setuju, 0\% tidak setuju dan masing masing $0 \%$ untuk jawaban ragu-ragu, kurang setuju dan tidak setuju.

\section{Detective Mechanism}

Detective mechanism merupakan mendeteksi modifikasi sistem dari pihak luar apabila mekanisme preventif gagal. Gambar 4 merupakan perbandingan nilai persentase karyawan PT. $\mathrm{XYZ}$ tentang detective mechanism.

\section{Detective Mechanism}

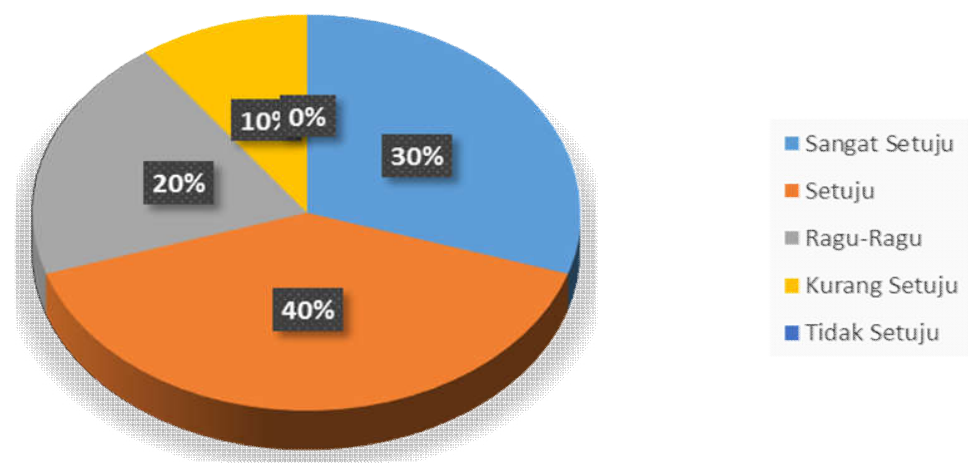

Gambar 4. DIAGRAM REKAPITULASI DETECTIVE MECHANISM

Berdasarkan rekapitulasi pada gambar 4 maka sebanyak 40\% karyawan PT. XYZ Salatiga setuju bahwa detective mechanism menjadi pengaruh keamanan sistem informasi fitur Internet Banking Bank BCA. Sebanyak 10\% kurang setuju, 20\% ragu-ragu, 30\% sangat setuju dan 0\% untuk jawaban tidak setuju. 


\section{Evaluasi Dimensi Availability}

Ada 2 komponen dalam dimensi Availability yang dijadikan indikator yaitu Access Speed dan Human Error.

\section{Access Speed}

Access speed merupakan kecepatan dalam penyediaan data informasi ketika dibutuhkan orang-orang yang memiliki otoritas dan akses. Gambar 5 merupakan perbandingan nilai persentase karyawan PT. XYZ tentang Accuracy and Consistency.

\section{Access Speed}

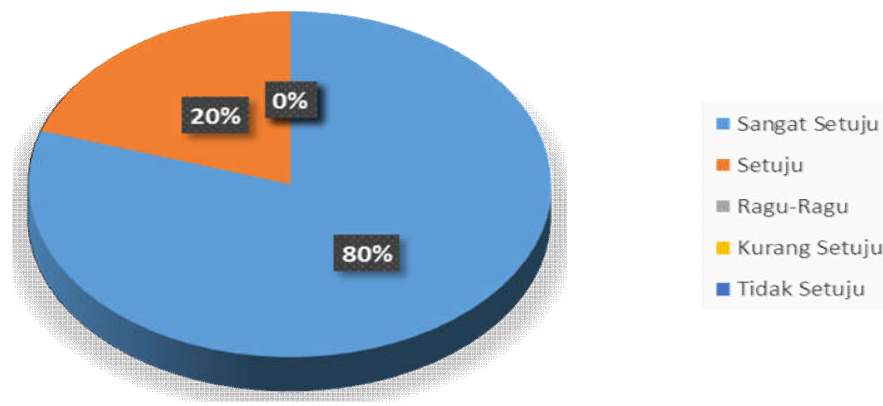

\section{Gambar 5. DIAGRAM REKAPITULASI ACCESS SPEED}

Berdasarkan rekapitulasi pada gambar 5 maka sebanyak 80\% karyawan PT. XYZ Salatiga sangat setuju bahwa access speed menjadi pengaruh keamanan sistem informasi fitur Internet Banking Bank BCA. Sebanyak 20\% setuju, dan masing - masing 0\% untuk jawaban rgu-ragu, kurang setuju dan tidak setuju.

\section{Human Error}

Human error merupakan faktor kelalaian manusia dapat juga mengakibatkan berkurangnya ketersediaan data. Gambar 6 merupakan perbandingan nilai persentase karyawan PT. XYZ tentang human error.

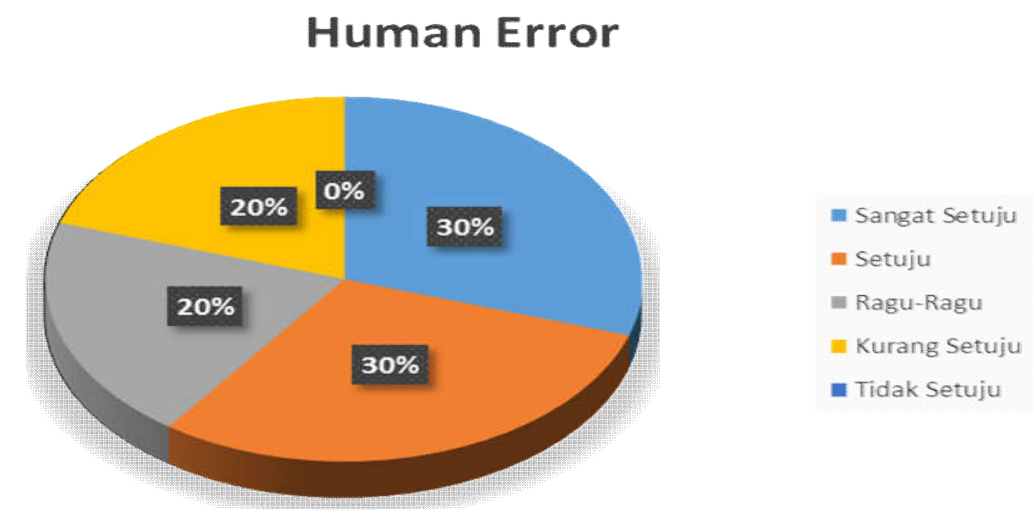

Gambar 6. DIAGRAM REKAPITULASI HUMAN ERROR 
INTENSIF, Vol.3 No.1 February 2019

ISSN: 2580-409X (Print) / 2549-6824 (Online)

Website: http://ojs.unpkediri.ac.id/index.php/intensif

Berdasarkan rekapitulasi pada gambar 6 maka sebanyak 40\% karyawan PT. XYZ Salatiga sangat setuju bahwa human error menjadi pengaruh keamanan sistem informasi pada fitur Internet Banking Bank BCA. Sebanyak 20\% kurang setuju, 20\% ragu-ragu, 0\% tidak setuju dan masing - masing $30 \%$ untuk jawaban sangat setuju dan setuju.

\section{Evaluasi Dimensi Keamanan Sistem Informasi}

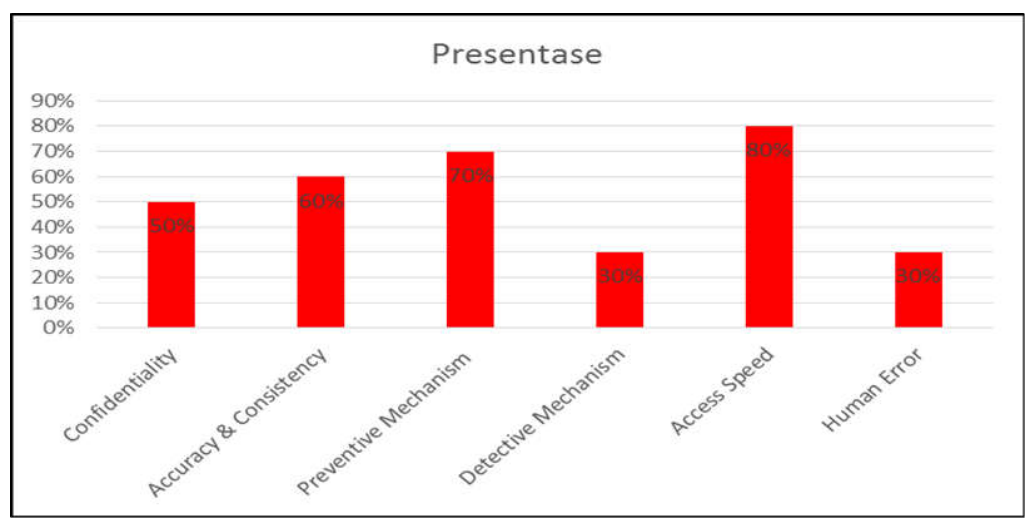

\section{Grafik 1. REKAPITULASI DIMENSI SISTEM KEAMANAN INFORMASI}

Dari evaluasi 3 dimensi dengan 6 indikator sistem keamanan informasi yang ada, dapat diketahui perbandingan nilai dalam bentuk persentase dimana akan dipilih dimensi-dimensi apa saja yang paling berpengaruh dalam proses keamanan sistem informasi fitur Internet Banking Bank BCA yang didapat dari responden karyawan PT. XYZ Salatiga yang dapat dilihat pada Grafik 1.

Berdasarkan evaluasi dan rekapitulasi jawaban responden karyawan PT. XYZ Salatiga sebagai berikut :

Bagi responden karyawan PT. XYZ Salatiga, dimensi yang paling mempengaruhi keamanan sistem informasi fitur Internet Banking Bank BCA dimensi availability dengan indikator access speed. Hal ini dapat dijadikan pertimbangan untuk jajaran management Bank BCA. Karena jumlah karyawan PT. XYZ Salatiga yang cukup besar dengan level perusahaan nasional sehingga potensi penambahan jumlah nasabah dari PT. XYZ Salatiga cukup mendongkrak peningkatan dana pihak ketiga.

Ketiga dimensi yang mempengaruhi keamanan sistem informasi yaitu dimensi confidentiality, integrity dan availabiility merupakan faktor yang berpengaruh positif dan dominan pada keamanan sistem informasi khususnya fitur Internet Banking di Bank BCA. 
INTENSIF, Vol.3 No.1 February 2019

ISSN: 2580-409X (Print) / 2549-6824 (Online)

Website: http://ojs.unpkediri.ac.id/index.php/intensif

\section{KESIMPULAN DAN SARAN}

Hasil analisis survei dimensi-dimensi yang mempengaruhi keamanan sistem informasi fitur Internet Banking Bank BCA dengan FGD technique di karyawan PT. XYY Salatiga menunjukkan bahwa bagi hampir seluruh karyawan PT. XYY Salatiga sebesar $80 \%$, menyatakan bahwa dimensi availability dengan indikator access speed adalah yang paling mempengaruhi keamanan sistem informasi fitur Internet Banking.

Hal ini dapat dijadikan rekomendasi bagi Bank BCA dalam hal peningkatan data security khususnya terkait Internet Banking. Sebagai contoh, BCA bisa memulai menggunakan teknologi criptography yang lebih canggih untuk mencegah terjadinya kerentanan terhadap data security.

\section{DAFTAR PUSTAKA}

[1] Pratiwi, "Penerapan Sistem Biometrik pada Nasabah Pengguna ATM (Studi kasus IKPIA Perbanas Jakarta)," JUTISI, vol. 5, no. 2, pp. 1042-1047, 2016.

[2] Suherman, P. Widodo, and D. Gunawan, "Efektivitas Keamanan Informasi Dalam Menghadapi Ancaman Social Engineering," J. Prodi Peperangan Asimetris, vol. 3, no. 1, pp. 73-90, 2017.

[3] O. Andriyani, H. Cangara, and S. Rhiza S, "Penggunaan Teknologi Informasi Online Dalam Kecepatan Pelayanan Dan Pengamanan Pada Bank BCA Makassar (Sebuah Studi Komunikasi Organisasi)," J. Komun. KAREBA, vol. 3, no. 1, pp. 58-67, 2014.

[4] R. Annisya and M. N. Hastuti, "Security System Layanan Internet Banking PT Bank Mandiri (Persero) Tbk.," J. Sist. Komput., vol. 2, no. 2, pp. 55-60, 2012.

[5] L. Salvina Helling, "Perancangan Sistem Informasi Pelayanan Pelanggan Pada Citra Laundry Bogor," INTENSIF, vol. 2, no. 1, pp. 68-78, 2018.

[6] S. Sucipto and J. Karaman, "Perancangan Sistem Informasi Strategis Balai Desa Gadungan Untuk Integrasi Sistem Informasi Publikasi," in Seminar Nasional Teknologi Informasi dan Multimedia 2015, 2015, p. 2.3-31-2.3-36.

[7] Kohar and P. Hanson Prihantoro, "Ancaman Keamanan pada Sistem Informasi Manajemen Rumah Sakit," SNIMed, vol. V, no. Seminar Nasional Informatika Medis, pp. 114-120, 2014.

[8] Ronny, "Enam Kekuatan Layanan Jasa Internet Banking: Tinjauan Dari Persepsi Nasabah," J. Organ. dan Manaj., vol. 13, no. 2, pp. 87-98, 2017.

[9] G. J. Lewis and K. J. Thygerson, Financial Institutions Internet Sourcebook. New York, USA: Mc Graw Hill, 1997.

[10] Paramita and L. Kristiana, "Teknik Focus Group Discussion Dalam Penelitian Kualitatif," Bul. Penelit. Sist. Kesehat., vol. 16, no. 2, pp. 117-127, 2013.

[11] F. Sonata, "Analisis Survei Faktor-Faktor Knowledge Sharing Dengan Teknik Focus Group Discussion (FGD) di STIKOM Medan,” J. Teknol. Inf. dan Komun., vol. 6, no. 1, pp. 29-40, 2017.

[12] T. Wahyudi, "Penerapan Knowledge Management Pada Perusahaan Web Hosting," Bianglala Inform., vol. 2, no. 2, pp. 45-55, 2014. 